\title{
Summary and analysis of the available information for the Ecosystem Approach to Fisheries management in Turkey
}

\author{
Adnan Tokaç ${ }^{1}$, Vahdet Ünal ${ }^{1}$, Zafer Tosunoğlu ${ }^{1}$, Altan Lök ${ }^{1}$, Tevfik Ceyhan ${ }^{1}$, \\ Hüseyin Özbilgin ${ }^{2}$ \\ ${ }^{1}$ Ege University Fisheries Faculty 35100 Bornova, İzmir, Turkey. E-mail: adnan.tokac@ege.edu.tr \\ ${ }^{2}$ Mersin University, Fisheries Faculty, Yenişehir Campus, Mersin, Turkey.
}

\begin{abstract}
Summary: This review has been prepared by Ege University, a partner of the CREAM Project, on the basis of data and information relevant to Turkish fisheries. To this end, data belonging to a total of 31 information sources produced from 19 fisheries studies were collected, investigated, and analysed. The data are heterogeneous and were obtained from scientific studies, national and international fisheries projects, regulations, management tools, and information on marine protected areas and no-take zones, all of which may be relevant to the ecosystem approach to Turkish fisheries. Analysis of these data shows that few studies have potential to serve the Ecosystem Approach to Fisheries (EAF) management in Turkey. In other words, there is a lot to be done in order to organize current fishing, aquaculture and other costal activities for EAF management, for which transition is targeted in Turkey's 10th five-year development programme. This review aims to present results of scientific research, decisions taken, applied enforcements, and a summary of presently used technical measures from the EAF perspective for sustainable fisheries. It also puts forward suggestions on strategies needed for transition to targeted EAF management in Turkey.
\end{abstract}

Keywords: EAF; ecosystem; sustainable fisheries; management measures; MPAs; fisheries management; Turkey.

Síntesis y análisis de la información disponible para el EAF en Turquía

Resumen: Esta revisión ha sido realizada por la Universidad de Ege, uno de los socios del proyecto CREAM, mediante el uso de datos e información relevante en las pesquerías de Turquía. Para ello se recogieron 31 formularios, obtenidos de 19 pesquerías, cuyos datos fueron investigados y analizados. Los datos presentan una estructura heterogénea, ya que se obtuvieron tanto de estudios científicos como de proyectos nacionales e internacionales de pesca, reglamentos, herramientas de gestión e información de áreas marinas protegidas y zonas donde no se realizan capturas, todas ellas relevantes para la aplicación del enfoque ecosistémico en las pesquerías turcas. El análisis de los datos muestra que pocos de los estudios llevados a cabo son relevantes para el enfoque ecosistémico de las pesquerías en Turquía. En otras palabras; hay mucho por hacer a fin de organizar la pesca actual, la acuicultura y otras actividades costeras si se quiere llegar a aplicar el enfoque ecosistémico en la gestión de la pesca. Esta transición se llevará a cabo mediante el $10^{\circ}$ programa de cinco años de duración en Turquía que tiene como principales objetivos la presentación de los resultados de las investigaciones científicas, decisiones tomadas, refuerzos aplicados, así como la presentación de un resumen de las medidas técnicas utilizadas en la actualidad desde la perspectiva de EAF para la pesca sostenible y por ultimo, la presentación de una serie de propuestas en relación a las estrategias necesarias para lograr la transición a la gestión EAF en Turquía.

Palabras clave: EAF; ecosistema; pesquerías sostenibles; medidas de gestión; zonas marinas progtegidas; gestión pesquera; Turquía.

Citation/Como citar este artículo: Tokaç A., Ünal V., Tosunoğlu Z., Lök A., Ceyhan T., Özbilgin H. 2014. Summary and analysis of the available information for the ecosystem approach to fisheries management in Turkey. In: Lleonart J., Maynou F. (eds), The Ecosystem Approach to Fisheries in the Mediterranean and Black Seas. Sci. Mar. 78S1: 29-36. doi: http:// dx.doi.org/10.3989/scimar.04022.18A

Editors: Jordi Lleonart and Francesc Maynou.

Received: October 18, 2013. Accepted: January 10, 2014. Published: March 28, 2014.

Copyright: () 2014 CSIC. This is an open-access article distributed under the Creative Commons Attribution-Non Commercial Lisence (by-nc) Spain 3.0. 


\section{INTRODUCTION}

The three decades following World War II were a period of rapid increase in fishing effort and landings, with significant collapses particularly in small pelagic fish stocks (Pauly 2009). Today, the Food and Agriculture Organization (FAO) reported that $87.3 \%$ of the world fish stocks have been fully exploited $(57.4 \%)$ and over exploited (29.9\%) in 2009 (FAO 2011). The need to consider natural changes as well as human activities when analysing and managing marine resources highlights the need to adopt an integrated view of complex ecosystems (Coll et al. 2013). Management of fisheries should be performed not only through the dynamics of target species, but also that of non-target species, by considering effects arising from anthropogenic activities and environmental and oceanographic factors, and assessing mutually with other stakeholders (Botsford et al. 1997, Cury et al. 2003, Duda and Sherman 2002, Cury et al. 2008, Bellido et al. 2011, Coll et al. 2013).

According to the FAO (2003), the purpose of an ecosystem approach to fisheries (EAF) is to plan, develop and manage fisheries in a manner that addresses the multiple needs and desires of societies, without jeopardizing the options for future generations to benefit from the full range of goods and services provided by marine ecosystems. The obligation to ensure sustainable exploitation of renewable fisheries resources has been recognized by many coastal states and considerable efforts have been made to improve fisheries management (FAO 1995; 1997, OECD 1997; 1999; 2003). The Turkish Government, though its ratification of various international conventions on environmental protection, demonstrates a commitment to the protection of coastal areas. Turkey has been a member of ICCAT since 2003, EUROFISH since 2002, the General Fisheries Commission for the Mediterranean (GFCM) since 1954 and the FAO since 1948 (Anonymous 2009). The implementation of an EAF can be based on various reports, directives and incentive programmes found at the level of European Union countries and at an international regional level covering the Mediterranean and the Black Sea (EC 2008, GFCM-SAC 2005, UNEP 2009, Coll et al. 2013)

The Mediterranean and Black Sea region is surrounded by many countries with different socio-economic characteristics. Among them, Turkey is the only country having borders on both seas. Turkish fishery production decreased by $8.34 \%$ in 2012 with respect to the previous year, reaching a total of $644852 \mathrm{t}$ (TurkStat 2013). The Turkish Statistical Institute reported that Turkey has 14300 fishing boats with a length of 5 $\mathrm{m}$ and above. From the 1970 to the 2000s, as a result of incentives, support and subsidies, there have been significant increases in the capacity of the Turkish fishing fleet in terms of number, length and engine power $(\mathrm{kW})$. These increases ultimately created overfishing pressure on fish stocks.

In the meantime, the Turkish fisheries management authority made significant progress within the framework of compliance with EU for transition to responsible and sustainable fisheries. Reducing the fishing fleet (initiating a buy-back programme for boats longer than $10 \mathrm{~m}$ ), activating a fisheries data processing system (SUBIS), reorganizing fisheries management (establishment of the Directorate General of Fisheries and Aquaculture), extending port offices, performing stock assessment studies for some species, initiating quota application, and introducing a fishing boat monitoring system may be counted as significant among these acquisitions. EAF was also included in a five-year development plan covering the period between the 2014 and 2018 and prepared by the Turkish Fisheries and Aquaculture Specialization Commission. However, these improvements were not considered as sufficient in EU progress reports.

Although the concepts underpinning EAF are not new, there has been little experience in attempting to implement them (FAO 2003). The EAF requires an effective fisheries management system and a sound management plan. A sound EAF management strategy also requires taking co-management into consideration. A management strategy to be prepared for an EAF consists of six steps and requires a 3- to 5-year study (Staples and Funge-Smith 2009). The first step is to determine specifications of current fishery in the region and the general situation of the region and stakeholders.

In this review, the general status of fishery in Turkey was analysed by considering the EAF, and it was questioned whether fishery in Turkey is ready to start EAF management. For this purpose, data collected in 31 information forms belonging to 19 studies which may be related to EAF management in Turkey were analysed and summarized. The work was carried out as part of an international project, CREAM ("Coordinating research in support to application of EAF (Ecosystem Approach to Fisheries) and management advice in the Mediterranean and Black Seas") (http://www. cream-fp7.eu/).

\section{A GENERAL OVERVIEW}

Studies and information related to the EAF in Turkey were stored by tabulating, and degree of density for each activity was determined. Afterwards, degrees of density of these activities were presented visually through radar charts (score system significance level from 0 at lowest to 3 at highest).

As a result of assessments performed related to activity types associated with the EAF in Turkey, it is seen that this activity type mainly consists of "research projects" (Fig. 1). These activities related to the EAF were mainly carried out on the Aegean Sea coasts of Turkey.

When making an assessment of studies performed until today related to the EAF in Turkey in terms of anthropogenic activities, it was realized that fishery activities were further analysed in these studies, but sufficient studies upon other activities have not been performed yet.

Information pertaining to current studies related to the EAF in Turkey is mostly gathered under the subheading of species and habitat. Therefore, at most one could expect to have information on species compo- 


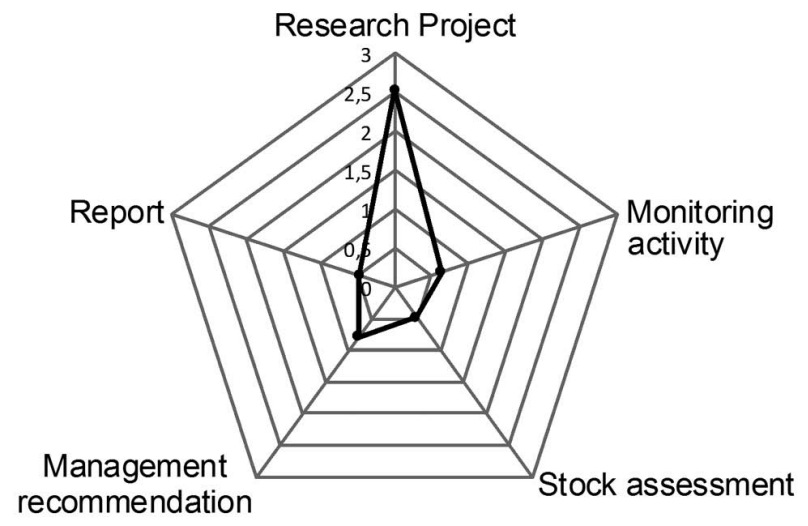

Fig. 1. - The overview of the activity type related to available information for the EAF in Turkey.

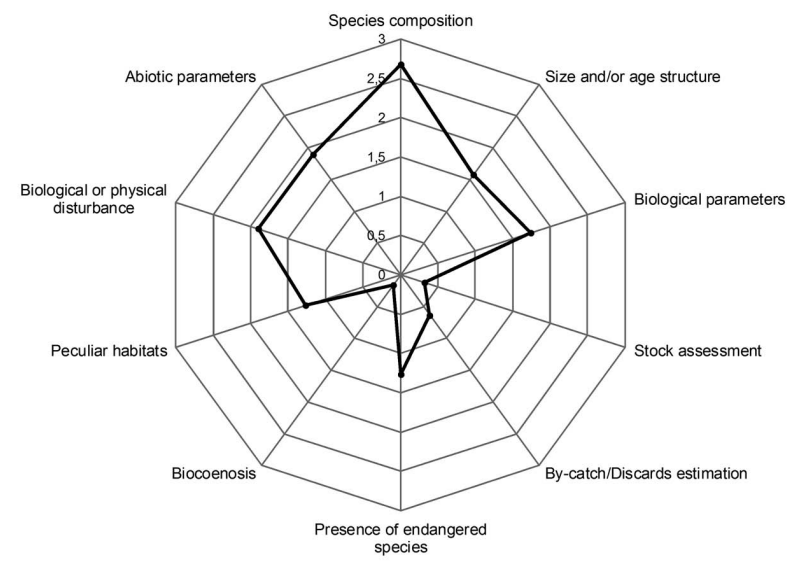

Fig. 2. - The overview of the species and habitat knowledge related to available information for the EAF in Turkey.

sition. Information related to length and age distribution along with abiotic and biological parameters, and biological and physical situation is provided at average level. It is seen that few studies exist about endangered species and special habitats, but it is realized that knowledge related to biocoenosis and stock assessment along with by-catch and discard estimation information is relatively low (Fig. 2).

Numeric information collected from the studies conducted in different disciplinary and areas related to EAF in Turkey is entirely at a low level. This information was provided from the studies performed on ecosystem indicators, stock estimation studies and bioeconomic modelling studies. Information and findings obtained from the studies associated with the EAF in Turkey are generally used in the suggestions related to spatial and temporal closures in fishery management. Suggestions related to limitations on fishing capacity and efforts along with technical measures followed this, and it may be asserted that results obtained from the studies conducted affect fishery management at an average level although not comprehensively (Fig. 3).

Finally, in the assessment performed on type and form of outputs obtained from these studies, it is seen

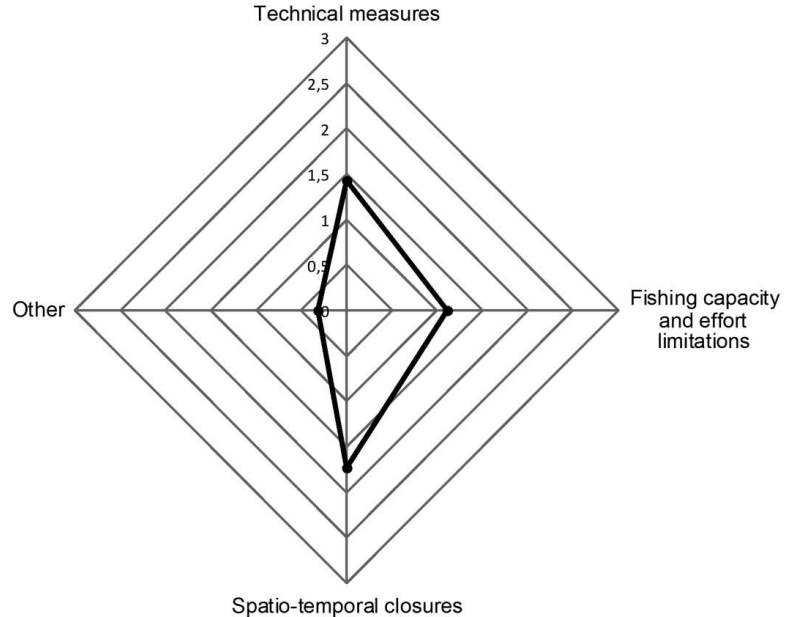

Fig. 3. - The overview of the fisheries management suggestions

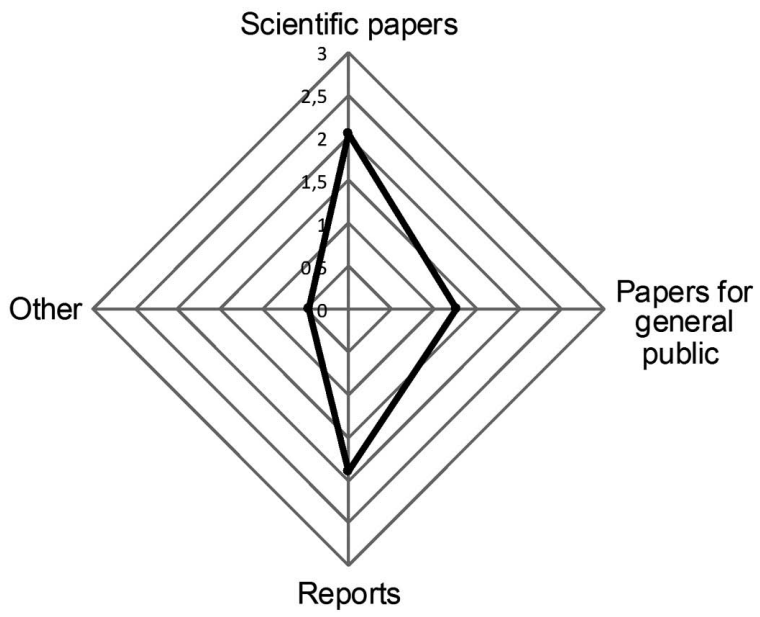

Fig. 4. - The public products as output related to available information for the EAF in Turkey.

that study outputs are mostly scientific papers, principally reports and articles. Apart from them, other output forms such as books, booklets, brochures, printed and visual media articles and interviews are used slightly (Fig. 4).

\section{CURRENT INSTRUMENTS RELATED TO THE EAF IN TURKEY}

Objectives of fisheries management policy in Turkey are set by the Ministry of Development. Managing fishery resources in a sustainable way is the main objective. Therefore, region-based (preliminary) plans have been designed. The objectives set out in these plans include rebuilding of depleted stocks, long-term resource management, fishing rights and, sustainability of fishing opportunities for fishermen.

The Directorate General for Fisheries and Aquaculture as a part of the Ministry of Food, Agriculture, and Livestock (MoFAL) is the main state organization responsible for fisheries management, including administration, regulation, protection, promotion, monitoring 
and technical assistance. These missions are carried out by five departments: Fishing and Control; Statistics and Information Systems; Aquaculture; Administrative Works and Coordination; and Resource Management and Infrastructures.

All fisheries activities are based on the Fisheries Law No. 1380 introduced in 1971, which provides a basis for the regulations and notifications on both commercial and recreational fisheries (Anonymous 2009). The need for a new law has become apparent due to changes taking place in fisheries, aquaculture, and related sectors. Presently a draft law (http://www.tarim.gov.tr/Sayfalar/ MevzuatDetay.aspx?rid=1011\&ListName=Mevzuat) is open to stakeholders' opinions.

Fisheries notification is prepared every four years by the MoFAL. It regulates protection of marine fisheries resources, liability limitation and bans related to fishing in order to ensure sustainable functioning by considering scientific, environmental, economic and social aspects for implementation in commercial fishing (Turkish Fisheries Regulation TFR No 3/1 2012). Conventional management measures (e.g. closed areas, closed seasons, minimum landing sizes, mesh size and shape, gear limitations) are dominating the regulation of Turkish fisheries.

\section{Buy-back programme}

Regarding the EAF, one of the most important management tools introduced and implemented by MoFAL is the buy-back programme, which aims to protect fish stocks by reducing fishing pressure for a sustainable fishery. Its first phase started in June 2012 for vessels of $12 \mathrm{~m}$ and above. A total of 364 vessels (19.5\% of the fleet in this size class) were bought back with a cost of 62.1 million Turkish liras. The second phase started in March 2013, covering also smaller vessels (10 m and above). In this phase 534 boat owners applied. Decommissioning will start in March 2014 with a payment of 67 million Turkish Liras. In both phases, vessel owners are paid 10, 15, and 20 thousand Turkish liras per metre of length for their vessels in size classes of 10-20 m, 20-30 m, and longer than $30 \mathrm{~m}$, respectively.

\section{Scientific studies (role of research in the manage- ment process)}

\section{Gear performance and catch composition studies}

Of the studies related to performance and catch composition of fishing gear used for fisheries in Turkey, a large proportion deal with bottom trawl fishing. It is realized that the studies conducted were generally on catch composition and size-frequency distribution of species. Trawl nets used in demersal trawl fishing in Turkey have changed in recent years from traditional nets used in Mediterranean trawl fishing to newer, more modern and effective trawl nets adapted from Atlantictype trawl nets. A similar transition has also started to be seen in the trawl boats used (GFCM:SAC11/2008/ Inf.16). More modern and effective trawl fishing will surely increase current fishing pressure on the stocks.
Thus, in the observations and personal communications made with the fishermen, it was stated that there is a significant decrease in fishing yield per boat. Most of the other fishing gears used in Turkish fisheries maintain their traditional structure. However, the materials used to construct them change with technology, price, and availability.

\section{Selectivity studies}

Gear selectivity studies in Turkish waters started in the mid-1980s, and concentrated especially on bottom trawl fishing (Tokaç et al. 1998). In fact, the majority of the gear selectivity studies made in Mediterranean countries were carried out in Turkish territorial waters (Stewart 2002). Through these studies, some technical results which can be used to reduce discard rate of some non-target species were obtained. These results generally consist of suggestions for increasing current mesh size. In the codend of bottom trawl in the Aegean and Mediterranean Sea, diamond mesh nets with a minimum size of $44 \mathrm{~mm}$ or square mesh net with a size of $40 \mathrm{~mm}$ are optionally used and mesh number around the codend is decreased. In order to improve selectivity, alternative designs such as full square mesh codends, square mesh escape windows and narrowed codends have been tested (Tokaç et al. 2009). Additionally, survival possibility of fish escaping from different codends has also been studied (Düzbastılar et al. 2010). Some of the studies on both codend selectivity and survival after escapement also consider the effect of seasonal variation (Özbilgin et al. 2007). Recently, a modelling study on predicting the size-selective properties of bottom trawl codends was carried out (Tokaç et al. 2014). Small-scale fishing activities in Turkish waters show great variety. A few studies have been conducted upon the selectivity of fishing gears used in small-scale fisheries, generally through gill nets and long lines (Karakulak and Erk 2008, Ceyhan et al. 2010). These passive fishing gears have a lower discard and non-target fishing rate than demersal trawls, so selectivity studies made on these fishing methods are numerically lower.

Although many technical, environmental and biological factors have affected selectivity, identification and modelling studies of selectivity of fishing gear continue advancing. Advancing selectivity of fishing gear is also important in terms of management of fisheries and economic aspects. In the meantime, it is observed that findings were not sufficiently taken into consideration in the management of fisheries. The majority of selectivity studies disregarded the economic impact assessment of implementation of alternative fishing gear or methods.

\section{Lost fishing gears and ghost fishing}

Studies on ghost fishing and its ecosystem effect have become of great interest in the last ten years. Ayaz et al. (2004) reports that annually $14.5 \%$ of gill and trammel nets commonly used in Izmir Bay are lost. The authors estimated that approximately $200-280 \mathrm{~km}$ 


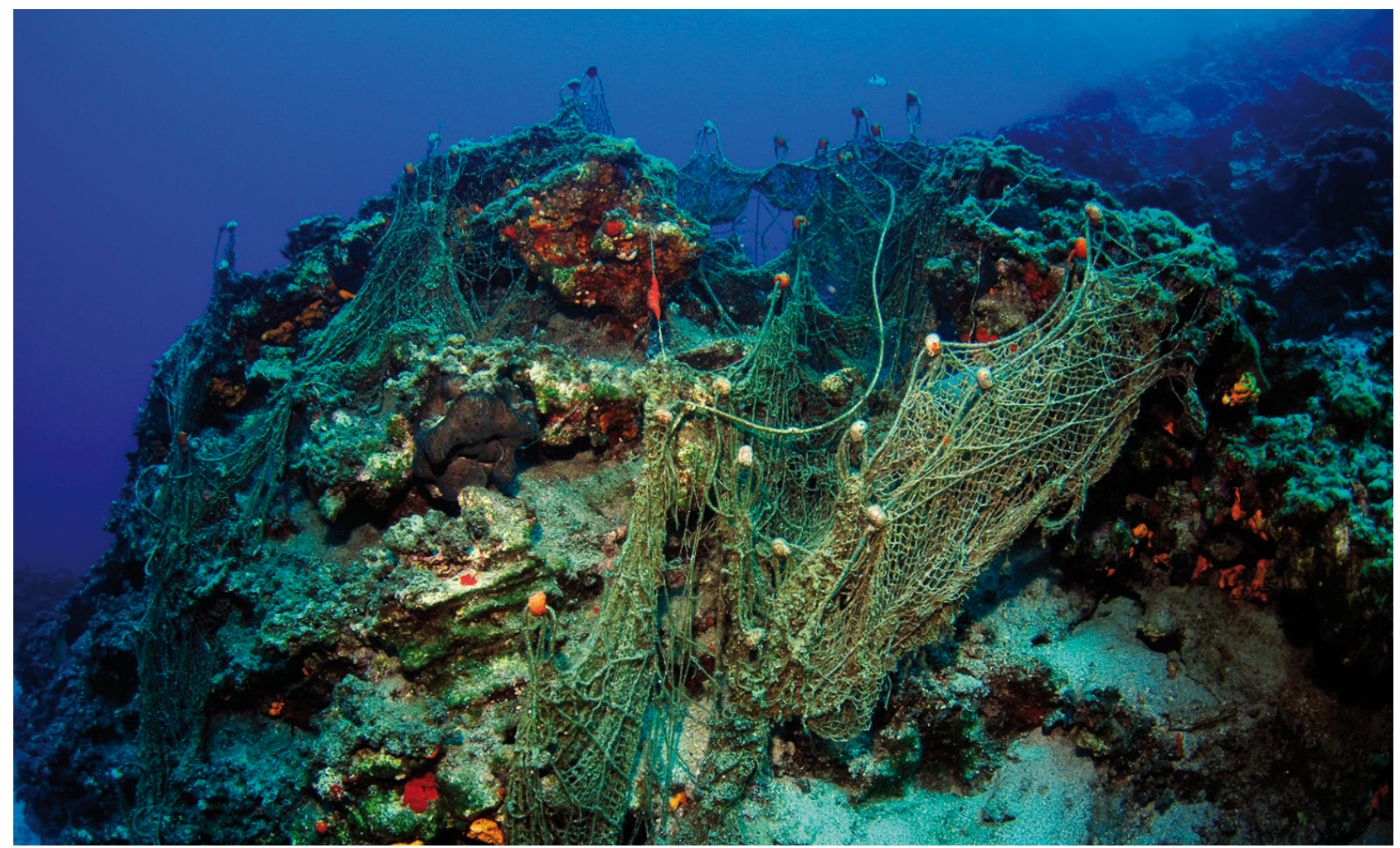

Fig. 5. - Underwater photograph of a derelict gillnet for public awareness (Photograph by Zafer Kizılkaya).

of set nets have been lost for various reasons in İzmir Bay in 2002. Furthermore, according to the results presented by Ayaz et al. (2010), 3.4\% of trammel nets, $0.8 \%$ of gillnets and $79.2 \%$ of long lines were lost in 2007. Nevertheless, there has been significant progress in the lost fishing gear and ghost fishing caused by them. First, a public awareness has been created (Fig. 5). Interest of NGOs, universities and administrative authorities on the subject has increased, and work on retrieval of lost gears, particularly ghost nets, has gained importance. Fishers clearly support such activities. Some projects are run by NGOs. At present, MoFAL plans to start a national project on retrieval of ghost nets and other lost fishing gears in Turkish seas, which is another important step for the health of the marine ecosystem.

\section{Stock assessment studies}

Almost 20 small pelagic fish species are commercially exploited in the Turkish seas and this number is being increased due to Lessepsian migration (Gücü 2012). Despite their commercial and ecological importance, this group composes the least-studied fishes in Turkish seas. The majority of the scientific studies for assessment of demersal fish stocks in Turkish seas have been carried out during the last 20-25 years (Tiraşın and Ünlüoğlu 2012). Stock assessment studies in Turkey are still at the early stage, and they are not sufficient to be used to guide fisheries management. Studies conducted until today are generally disconnected from each other, consisting of local studies in discontinuous time intervals. Continuous data and time series, which are one of the most important characteristics sought for this kind of studies, do not exist. During the negotiations made about EU Acquires on fisheries between Turkey and the European Union, inadequacy of stock assessment studies was one of the most important deficiencies. In order to eliminate this deficiency to a certain extent, a national study for the assessment of anchovy stocks in the Black Sea was initiated in 2011.

Other studies (by-catch, discard, IUU fishing, marine litter, alien species, etc.)

A few studies have considered by-catch and discard. The most appropriate present data obtained in Turkey belong to bottom trawl fishing in Mersin Bay located in the northeastern Mediterranean Sea, where the average discard rate is $48 \%$ by weight and $70 \%$ by number of individuals. Marine debris (plastic bottles, tyres, cans etc.) within trawl fishing composition are also studied. As a result of a two-year observation, Özbilgin et al. (2013) report that marine debris in trawl catch composition in Mersin Bay is $4 \%$ by weight.

Illegal, unreported and unregulated fishing (IUU) is believed to be of the most serious threats for longterm sustainability of fisheries. IUU fishing constitutes $20 \%-25 \%$ of overall fishing worldwide (Anonymous 2008). However, there is no national research showing the amounts or figures of illegal fishing in Turkey. Another of the most important problems experienced in fisheries management in Turkey is the inability to keep reliable fishing data.

The phenomenon of alien or exotic species in the Black Sea and Mediterranean Sea has been recorded 
for several decades. It has speeded up in recent years, with many examples of negative impacts on marine ecosystems, on the local marine fauna and flora, and on socio-economic activities, such as fisheries and tourism. The Black Sea and Mediterranean Sea are interconnected by the Turkish Straits System (Öztürk and Turan 2012). Recent information indicated a total of 400 alien species assessed from the entire Turkish seas (Çınar et al. 2011).

\section{Marine Protected Areas (MPAs)-No Take Zones (NTZs) and fisheries co-management}

TVKGM (2014) reported that a total of $31 \mathrm{Ma}-$ rine and Coastal Protected Areas (MCPAs) covering 713079 ha with a marine component of 346138 ha $-4 \%$ of the Turkish coastal waters - established as of 2011 on the Mediterranean coasts of Turkey. In order to strengthen the MCPAs System of Turkey, the "PIMS 3697: Strengthening the System of MCPAs Project" starting on 29 May 2009 will help to strengthen the national MCPAs system and catalyse its efficient management, as well as implementing protected area study programmes within the International Biodiversity Agreement and the Barcelona Agreement. Moreover, it is aimed to extend Marine and Coastal Protection Areas of Turkey at the rate of $44 \%$ : in other words approximately 100000 ha in 2010 . In the meantime, the targets include the establishment of restricted areas for fishing and, accordingly, protection of biological diversity of national marine areas and a contribution to fisheries management (TVKGM 2014).

The importance of MPAs is clear in terms of fisheries, but NTZs play a more important and better role in recovering fish stocks, supporting fishermen and marine living resources. Although the benefits of reserve areas are known, announcement of any area as a NTZ is quite difficult and requires acting together with fishermen and other stakeholders and receiving their approval. The concept of co-management emerges at this point and can be simply defined as a partnership of fisheries management authorities and fisheries stakeholders. However, the degree of co-management increases along the range from "informative" to "community control" of the continuum (Berkes et al. 2001). Fisheries co-management in Turkey appears in the form of "consultation", which means that the government unit responsible for fisheries management has the mechanism to act on fisheries but it takes all decisions by itself in general. In the meantime, Turkish fishermen have become a significant organized power along with 516 fishery cooperatives, 16 regional unions and 1 central union. In recent years, this power has undertaken important duties in directing problems related to fisheries to relevant platforms, discussing and finding solutions.

\section{Artificial reefs for habitat and biodiversity protection}

It is seen that artificial reefs are successfully used in the protection of biodiversity and sensitive ecosystems such as seagrass, preventing illegal trawl activities and supporting traditional small-scale fisheries (Lök et al.
2002). Thirty four artificial reef projects have been carried out along the Turkish Coast since 1991. The National Artificial Reef Master Plan was prepared by the Directorate General for Fisheries and Aquaculture of the MoFAL in 2008. Within the framework of this plan, the first pilot project was completed in February 2013.

Results obtained from artificial reef implementation on the coasts of Turkey indicate that artificial reefs may be a tool which can be used within an EAF as marine protection areas when sound planning and participation of stakeholders are ensured (Lök et al. 2011).

\section{DISCUSSION AND CONCLUSIONS}

Four main EAF aspects, the biotic, abiotic, fishery and institutional components, should be determined in order to make the description of interaction between fisheries and the ecosystem (Garcia et al. 2003). The present study provides information relevant to these four components and discusses the present state of Turkish Fisheries for transition to EAF in Turkey. Very important scientific studies, institutional settlements, co-management actions and regulations which support EAF management are currently being carried out in Turkey.

Presently used conventional fisheries management measures such as closed areas, closed seasons, minimum landing size, mesh size and shape regulations are usually updated by taking the academic studies as a reference. In regulations pioneered by scientific studies, socio-economic conditions, opinions, needs and expectations of fishers are taken into account as much as possible. In recent years, fishery cooperatives and NGOs have started to be more effective in the decision making process. Fisheries co-management and use of traditional knowledge, which form an important part of an EAF are improved and better understood day by day. The determination and willingness of the state for sustainable fisheries in Turkey is demonstrated by the establishment of the Directorate General for Fisheries and Aquaculture, progress on a New Fisheries Low, a buy-back programme with a budget of approximately 40 million euros, and an increase in the numbers and areas of artificial reefs, NTZs and MPAs. Despite all these positive progresses to ease the transition to EAF in Turkish fisheries, there are also gaps and necessities which are not sufficiently fulfilled. For example, monitoring and stock assessment studies that play a key role for EAF also require a considerable budget and therefore cannot be conducted at the desired level.

It is generally accepted that discards in fisheries are the key subject for the EAF and in order to have a healthy marine ecosystem, decreasing the amount of discard in fishing activities would serve considerably (Bellido et al. 2011). However, discards and non-target fishing pose complicated biological, technologic and economic problems that are fairly difficult to solve. Selectivity studies are generally considered as a tool for achieving success in discards and non-target fishing in Turkey, and studies made on these issues are generally associated with the selectivity of fishing gears instead of their effects on the ecosystem. 
Most of the studies which may be associated with the EAF method in Turkey are selectivity studies. By increasing selectivity in fishing gears, the opportunity for decreasing discard is increased. Zhou et al. (2010) state that protection of sensitive species and appropriate regulation of fishing pressure are required, indicating that less selective fishing gears will assist biodiversity and its continuity. This potential difference between the opinion supporting the use of more selective fishing gears and the ecosystem approach should be studied in relation to the most appropriate scientific view by both theoreticians and implementers (Kelleher 2005, Bellido et al. 2011). It should be noted here that although many studies have now been carried out on discards and selectivity of fishing gears in Turkey, the results of these studies have not been implemented in practice in order to create concrete impacts on marine ecosystem.

Successful fisheries management plans depend, in large part, on the accuracy of the available data (Ünal 2010). Given the growing emphasis on ecosystembased management, it is important to have a comprehensive understanding of total fishery removals in order to assess long-term trends and make more informed decisions regarding resource use (Ulman et al. 2013). Fisheries are economic activities and, thus, the requirement is for advice that takes into account both the economic feasibility of fisheries and the health of the ecosystem (Lassen et al. 2013).

Fisheries Management is one of the most important aspects of Turkish fisheries policy. Recently, great importance has been placed on controlling catches and fishing effort and ensuring sustainability. To this end, several important projects have been carried out and the on-going project also aims to form a basis for development of an EAF management system. In fact, even the present situation is sufficient to adopt EAF in Turkish Fishery. The biggest challenge here is to create willingness and a better understanding of EAF among relevant stakeholders.

\section{ACKNOWLEDGEMENTS}

This paper was written with financial support from the European Union within the scope of the FP7 CREAM/265648 Project. It does not necessarily reflect the European Commission's views and in no way anticipates its future policy. We would like to thank project coordinator and WP leaders, particularly Paolo Sartor (WP2 leader) and Joel Vigneau (WP3 leader), in addition to all project partners. We would also like to thank the editors and anonymous referees for their helpful comments in our manuscript.

\section{REFERENCES}

Anonymous 2008. Stop illegal fishing. The programme of support to tackling IUU fishing in southern Africa. The impact of flags and ports of noncompliance in the SADC region. Volume 2-Report, $57 \mathrm{p}$.

Anonymous 2009. Turkish Fisheries. The Ministry of Agriculture and Rural Affairs, Directorate of Mediterranean Fisheries Research, Production and Training Institute, Kepez - Antalya Turkey, $28 \mathrm{p}$.

Ayaz A., UUnal V., Özekinci U. 2004. An investigation on the deter- mination of amount of lost set nets which cause ghost fishing in Izmir Bay. J. Fish. Aquat. Sci. 21: 35-38.

Ayaz A., Ünal V., Acarlı D., Altınagac A., 2010. Fishing gear loss in Gökova Special Environmental Protection Area (SEPA), (Eastern Mediterranean), Turkey. J. Appl. Ichthyol. 26: 416-419. http://dx.doi.org/10.1111/j.1439-0426.2009.01386.x

Bellido J., Santos M., Pennino M., Valeiras X., Pierce G.J. 2011. Fishery discards and bycatch: solutions for an ecosystem approach to fisheries management? Hydrobiologia 670: 317-333. http://dx.doi.org/10.1007/s10750-011-0721-5

Berkes F., Mahon R., Mcconney P., Pollnac R.C., Pomeroy R.S. 2001. Managing small-scale fisheries: alternative directions and methods. International Development Research Centre, Ottawa, 308 pp.

Botsford L.W., Castilla J.C., Peterson C.H. 1997. The management of fisheries and marine ecosystems. Science 277(5325): 509 http://dx.doi.org/10.1126/science.277.5325.509

Ceyhan T., Hepkafadar O., Tosunoğlu Z. 2010. Catch and size selectivity of small-scale fishing gear for the smooth-hound shark Mustelus mustelus (Linnaeus, 1758) (Chondrichthyes: Triakidae) from the Aegean Turkish coast. Medit. Mar. Sci. 11: 213-223. http://dx.doi.org/10.12681/mms.73

Çınar M.E., Bilecenoglu M., Özturk B., Katağan T., Yokes M.B., Aysel V., Dağlı E., Açık S., Özcan T., Erdoğan H. 2011. An updated review of alien species on the coast of Turkey. Medit. Mar. Sci. 12: 275-316. http://dx.doi.org/10.12681/mms.34

Coll M, Cury P., Azzurro E., Bariche M., Bayadas G., Bellido J.M., Chaboud C., Claudet J., El-Sayed A.F., Gascuel D., Knittweis L., Pipitone C., Samuel-Rhoads Y., Taleb S., Tudela S., Valls A., Workshop Participants. 2013. The scientific strategy needed to promote a regional ecosystem-based approach to fisheries in the Mediterranean and Black Seas. Rev. Fish Biol. Fish. http://dx.doi.org/10.1007/s11160-013-9305-y

Cury P., Shannon L., Shin Y.J. 2003. The functioning of marine ecosystems: a fisheries perspective. Chapter 7. In: Sinclair M., Valdimarsson G. (eds), Responsible fisheries in the marine ecosystem. Cabi Publishing and FAO, Wallingford, pp. 103-124. http://dx.doi.org/10.1079/9780851996332.0103

Cury P.M., Shin Y.J., Planque B., Durant J.M., Fromentin J.M., Kramer-Schadt S., Stenseth N.C., Travers M., Grimm V. 2008. Ecosystem oceanography for global change in fisheries. Trends Ecol. Evol. 23(6): 338-346. http://dx.doi.org/10.1016/j.tree.2008.02.005

Duda A.M., Sherman K. 2002. A new imperative for improvingmanagement of large marine ecosystems. Ocean Coast.Manag. 45(11-12): 797-833. http://dx.doi.org/10.1016/S0964-5691(02)00107-2

Düzbastılar F.O., Aydın C., Metin G., Lök A., Ulas A., Özgül A., Gül B., Metin C., Özbilgin H., Şensurat T., Tokaç, A. 2010. Survival of fish after escape from a $40 \mathrm{~mm}$ stretched diamond mesh trawl codend in the Aegean Sea. Sci. Mar. 74(4): 755-761. http://dx.doi.org/10.3989/scimar.2010.74n4755

EC 2008. Directive of the European Parliament and the Council Establishing a Framework for Community Action in the Field of Marine Environmental Policy (Marine Strategy Framework Directive). European Commission Directive2008/56/EC, OJL $164 \mathrm{pp}$.

FAO 1995. Living Marine Resources and Their Sustainable Development. Some Environmental and Institutional Perspective. Fisheries Technical Paper No 353, Rome. 167 pp.

FAO 1997. Fisheries Management. Technical Guidelines for Responsible Fisheries. No 4, Rome. 82 pp.

FAO 2003. The Ecosystem approach to fisheries. FAO Technical Guidelines for Responsible Fisheries 4, Suppl. 2, Rome, 112 pp.

FAO 2011. Review of the state of world marine fishery resources. FAO Fisheries and Aquaculture Technical Paper No. 569. Rome, 334 pp.

Garcia S.M., Zerbi A., Aliaume C., Do Chi T., Lasserre, G. 2003. The ecosystem approach to fisheries. Issues, terminology, principles, institutional foundations, implementation and outlook. FAO Fisheries Technical Paper. No. 443. FAO, Rome, 71 pp.

GFCM:SAC11/2008/Inf.16 2008. Report of the SCMEE transversal working group on selectivity. Sète, France, 2-4 July 2008.

GFCM-SAC. 2005. SCMEE Transversal workshop on ecosystem approach to fisheries. General Fisheries Commission for the Mediterranean (GFCM). Scientific Advisory Committee (SAC). Sub-Committee on Marine Environmentand Ecosystems (SCMEE), Salammbo, Tunisia. 
Gücü A.C. 2012. Small pelagic fish and fisheries in Turkey. In: Tokac A., Gücü A.C., Öztürk B. (eds), The State of the Turkish Fisheries. Turkish Marine Research Foundation Publication Number: 34, Istanbul, Turkey.

Karakulak F.S., Erk H. 2008. Gill net and trammel net selectivity in the northern Aegean Sea, Turkey. Sci. Mar. 72: 527-540

Kelleher K. 2005. Discards in the world's marine fisheries. An update. FAO Fisheries Technical Paper No. 470. Rome: 131 pp.

Lassen H., Pedersen S.A., Frost H., and Hoff. A. 2013. Fishery management advice with ecosystem considerations. ICES J. Mar. Sci. 70: 471-479. http://dx.doi.org/10.1093/icesims/fss208

Lök A., Metin C., Ulaş A., Düzbastılar F.O., Tokaç A. 2002. Artificial reefs in Turkey. ICES J. Mar. Sci. 59S: 192-195. http://dx.doi.org/10.1006/imsc.2002.1221

Lök A., Düzbastılar F.O., Gül B., Özgül A., Ulaş A. 2011. The role of artificial reefs in fisheries management in Turkey. In: Bortone S. A., Brandini F. P., Fabi G., Otake S. (eds) Artificial Reefs in Fisheries Management CRC Press Taylor and Francis Group, Marine Biology Series. pp. 155-166. http://dx.doi.org/10.1201/b10910-11

OECD 1997. Management Systems in OECD countries. Organisation for Economic Cooperation and Development. http://www. oecd.org 10.02.2010.

OECD 1999. Management Systems in OECD countries. Organization for Economic Cooperation and Development. http://www. oecd.org. 10.02.2010.

OECD 2003. Management Systems in OECD countries. Organisation for Economic Co-operation and Development. http://www. oecd.org. 10.02.2010

Özbilgin H., Tosunoğlu Z., Tokaç A., Metin G. 2007. Seasonal variation in the trawl codend selectivity of picarel (Spicare smaris). ICES J. Mar. Sci. 64: 1569-1572. http://dx.doi.org/10.1093/icesjms/fsm115

Özbilgin H., Gökçe G., Özbilgin Y., Eryaşar A.R., Kalecik E., Bozaoğlu A.S. 2013. Investigations on increasing size and species selectivity in Mersin Bay Trawl Fishery. TUBITAK project No. 1090684 TÜBİTAK, 250 pp.

Öztürk B., Turan C. 2012. Alien Species in the Turkish Seas. In: Tokaç A., Gücü A.C., Öztürk B. (eds), The State of the Turkish Fisheries. Turkish Marine Research Foundation Publication Number: 34, İstanbul, Turkey.

Pauly D. 2009. Beyond duplicity and ignorance in global fisheries. Sci. Mar. 73: 215-224. http://dx.doi.org/10.3989/scimar.2009.73n2215

Staples D., Funge-Smith S. 2009. Ecosystem approach to fisheries and aquaculture: Implementing the FAO Code of Conduct for Responsible Fisheries. FAO Regional Office for Asia and the Pacific, Bangkok, Thailand. RAP Publication 2009/11, 48 pp.

Stewart A.M. 2002. A review of studies of fishing gear selectivity in the Mediterranean, Fishing gear selectivity studies in the
Mediterranean. In: Robles R., Hernández P. (eds), A review and a summary of the 2001 COPEMED Workshop report.

Tıraşın E.M., Ünlüoğlu A. 2012. Demersal and deep water fisheries resources in Turkish Seas. In: Tokaç A., Gücü A.C., Öztürk B. (eds), The State of the Turkish Fisheries. Turkish Marine Research Foundation Publication Number: 34, İstanbul, Turkey.

Tokaç A., Lök A., Tosunoğlu Z., Metin C., Ferro R.S.T.. 1998. Codend selectivities of a modified bottom trawl for three fish species in the Aegean Sea. Fish. Res. 39: 17-31. http://dx.doi.org/10.1016/S0165-7836(98)00172-6

Tokaç A., Özbilgin H. Kaykaç, H. 2009. Alternative codend designs to improve size selectivity for Norway lobster (Nephrops norvegicus) and Rose shrimp (Parapenaeus longirostris) in the Aegean Sea. Crustac. Int. J. Crustac. Res. 82: 689-702 http://dx.doi.org/10.1163/156854009X407696

Tokaç A., Herrmann B., Aydın C., Kaykaç H., Ünlüler A., Gökçe G. 2014. Predictive models and comparison of the selectivity of standard (T0) and turned mesh (T90) codends for three species in the Eastern Mediterranean. Fish. Res. 150: 76-88. http://dx.doi.org/10.1016/j.fishres.2013.10.015

Turkish Fisheries Regulation (TFR) No 3/1 2012. The commercial fish catching regulations in 2012-2016 fishing period: Notification No. 2012/65. Republic of Turkey. Ministry of Food, Agriculture and Livestock, General Directorate of Fisheries and Aquaculture, Ankara, 112 pp. (in Turkish).

TurkStat 2013. Turkish Statistical Institute (TÜİK) News Release, No: 13551 .

TVKGM 2014. The National Strategy of Marine and Coastal Protected Areas of Turkey (in Turkish). PIMS 3697: Strengthening the System of the Marine and Coastal Protected Areas of Turkey Project. Technical Report Series 21: 52 pp. (in press).

Ulman A., Bekişoğlu S., Zengin M., Knudsen S., Ünal V., Mathews C., Harper S., Zeller D., Pauly D. 2013. From bonito to anchovy: a reconstruction of Turkey's marine fisheries catches (1950-2010). Medit. Mar. Sci. 14: 309-342. http://dx.doi.org/10.12681/mms.414

Ünal V. 2010. Fishery management in Gökova Special Environment Protection Area. In: Kıraç C.O., Veryeri N.O. (eds), Putting PEEN to practice in Marine and Coastal Areas; Gokova Integrated Coastal and Marine Management Planning Project. Final Report. BBI Matra, Netherlands. pp. 1-92.

UNEP 2009. Implementing the ecosystem approach in the Mediterranean. MED waves, the magazine of the Mediterranean Action Plan 58: 1-20.

Zhou S., Smith A.D.M., Punt A.E., Richardson A.J., Gibbs M., Fulton E.A., Pascoe S., Bulman C., Bayliss P., Sainsbury K. 2010. Ecosystem-based fisheries management requires a change to the selective fishing philosophy. Proc. Nat. Acad. Sci. USA 107: 9485-9489.

http://dx.doi.org/10.1073/pnas.0912771107 